\title{
CORRUPTION RISK MANAGEMENT IN THE CUSTOMS AUTHORITIES OF THE EURASIAN ECONOMIC UNION IN THE CONTEXT OF NATIONAL SECURITY
}

The article considers the phenomenon of corruption, its essence, causes and consequences. The social, economic, and political changes that globalization has brought have been accompanied by some challenges. One of them is corruption. Corruption occurs at all levels of society around the world, from local and national governments, civil society, judiciary functions, large and small businesses, military and other services including Customs service. Corruption poses a serious danger to national security, economic security and innovative security of any State. Corruption represents the basic threat for economic security of the state, affecting the expansion of the shadow economy, rising inflation, increasing the level of commercial and financial risks, as well as stimulating the inefficient use of budget funds. As for the Eurasian Economic Union, so problem of corruption within it, including corruption in the customs authorities, is highly relevant. It can be ascertained, that the need to study the existing methods for managing corruption risks in the customs authorities of the Eurasian Economic Union, their strengths and weaknesses, as well as potential areas for improvement. The World Customs Organization has drawn attention to the international character of this phenomenon and, in our opinion, has developed a unified approach and methodology for studying corruption processes in the customs sphere. Close attention is paid to corruption in customs authorities, which has specific features. A comparative economic analysis of corruption backgrounds in the customs authorities of the Eurasian Economic Union is carried out. The essence is that in the Eurasian Economic Union the volume of corruption in Customs bodies is directly proportional to the volume of inflation and inversely proportional to the volumes of Customs officers' salaries, Customs payments and foreign direct investments. Taking into account all mentioned above we can will move to the measures aimed to prevent and repress corruption. All in all, there is a great variety of innovative measures effectively used by foreign countries. Anti-corruption tools operating in the practices of foreign countries are considered. The ways of improving counteracting of corruption, anti-corruption tools in the customs authorities of the Eurasian Economic Union are defined.

Key words: Government Policy, corruption, corruption risks, national security, economic security, customs authorities, anti-corruption tools.

JEL Classification: D73, D78, F52.

\section{Gennadiy BROVKA,}

Dean Faculty of Management Technologies \& Humanities Belarussian National Technical University,

PhD, Associate Professor

gbrovka@bntu.by

https://orcid.org/0000-0001-6135-6738

\section{Introduction}

In the modern era, characterized by the intensification of the globalization process, along with such positive phenomena as optimizing the use of resources, expanding the assortment, improving the quality of manufactured goods and services, facilitating access to the latest achievements of scientific and technological progress, we can increasingly observe the enlargement of the scale of various kinds of contradictions, manifested in the emergence of new complex threats and risks. These phenomena (threats) are associated with the onset of a systemic crisis, the bright precursors of which are not only the spread of transnational crime, the deformation of public institutions, the distortion of such key concepts as the "welfare state" and "social state", but also the spread of corruption.

In recent years, corruption is often perceived by people as very tolerant. It falsely seems to be a structural element of the state system, called, as V.A. Nomokonov wrote, to fulfill the role of "a kind of lubricant for the rusty gears of the state mechanism ("if you don't grease the wheels, the cart won't go"), which leads only 
to "even greater corrosion, deformation of state institutions" (Nomokonov, 2001: 166); aggravation and complication of existing internal problems, one of which is the formation of such gaps in the state's national security system (in particular, in its economic component) as a decrease in budget revenues, a decrease in investment attractiveness, the outflow of foreign and domestic capital abroad, and the suppression of fair competition. It should be noted that various sciences consider the concept of corruption from different perspectives: by lawyers as an illegal act; by political scientists as a way of influencing financial and political activity; by sociologists as a phenomenon reproducing cultural traditions; by economists as a way of rationalizing costs by businesses and obtaining additional income by officials, and even by Z. Freud's followers - psychologists as a manifestation of unconscious desire, etc.

It should be noted that there are a number of markets for corruption services that have a direct impact on the economic security of any state. These markets include the state market of customs services. The World Customs Organization has long drawn attention to the international character of this phenomenon and, in our opinion, has developed a unified approach and methodology for studying corruption processes in the customs sphere.

At the end of the 20th century, J.W. Shaver, the 6th Secretary General of the World Customs Organization, noted that "there are only a small number of government bodies in which the classical prerequisites for institutional corruption would be as" successfully "presented as in customs administrations" (McLinden, Durrani, 2013: 4). This is due to the fact that, being monopolistic, customs activity is associated with the empowerment of both senior and junior officials involved in the implementation of such basic functions of the customs authorities as control over the correctness of determining the country of origin of goods, customs value, and product classification; customs control; collection of customs and other payments; the issuance of various certificates, decisions, etc., which are characterized by researchers as corruption vulnerable (McLinden, Durrani, 2013: 4). In addition, like other state bodies, customs authorities take part in public procurement and conduct financial and economic activities (acquisition, spending, distribution of material and technical means), which can also be considered an area of high corruption risks.

As for the Eurasian Economic Union (hereinafter - the EAEU), the problem of corruption within it, including corruption in the customs authorities, is highly relevant. The indicated position is confirmed by the data of sociological studies. According to the results, respondents from Belarus note a moderate level of corruption in customs, from Russia and Kazakhstan - significant. Negative is the fact that there are no detailed data on Armenia and Kyrgyzstan, which probably indicates the fears of respondents regarding participation in polls. It can be perceived as an expression of a political position that runs counter to the official state course. It is also noteworthy that almost three quarters of those polled consider anticorruption legislation ineffective and do not have confidence in existing anti-corruption measures (Miller \& Chevalier, 2018).

Summarizing the above, we can state the need to study the existing methods for managing corruption risks in the customs authorities of the EAEU, their strengths and weaknesses, as well as potential areas for improvement.

\section{Outcomes and discussion}

In the most general form, without affecting the established regulatory definitions, corruption can be described as a complex socially dangerous phenomenon that manifests itself in various forms of abuse of state or other powers to obtain benefits for personal purposes or in the interests of third parties (Simanovskiy, 2017: 123). At the same time, the analysis of the above definition allows us to establish that concepts such as "power", "state bodies", and "officials" are used as an attribute element of the definition. This is explained by the fact that each definition implicitly refers us to the root cause of corruption manifestations laid down in the very essence of social structure, based on the need to identify a group of people and special institutions engaged in control functions that imply a special authority, to dispose of any resources and the right to make important decisions. Further development of the phenomenon of corruption, as a rule, occurs under the influence of secondary, or stimulating, reasons, which include excessive state intervention in the economy, low level of development of civil society, the complexity of legislation, etc.

Corruption poses the main threat to the economic security of the state, affecting the expansion of the shadow economy, rising inflation, increasing the level of commercial and financial risks, as well as stimulating the inefficient use of budget funds. Regarding the specifics of the actual threats to the economic security, it should be noted that, even in undeveloped form they are quite intense inhibitors 
of the development of the state, oppressive functioning of each of its basic systems, and, reaching their zenith, can cause absolute economic inefficiency, deep poverty of the population, critical deformation or the fall of the political system.

Corruption in the customs authorities poses a particular threat to the economic security of the state. It is obvious that the phenomenon of corruption in the customs authorities is not fundamentally new and existed in ancient times. Thus, D. Widowson, referring in his studies to the work of H. Asakura, argues that in ancient Rome, where the first tariff was created, customs officials had duties to control the payment of customs duties in the proper amount and to suppress smuggling. At the same time, "it would be reasonable to assume that some officials have made it a rule to demand that traders give Caesar what belongs to Caesar, plus a little more to fill their pockets" (Widdowson, 2013: 11).

Analyzing the above provisions, it can be noted that corruption in the customs authorities originated in the form of bribery, but it is fundamentally wrong to consider it the only form of corruption in the customs authorities. Publications in the media allow us to state the existence of corruption in the customs authorities also in the form of "kickbacks" in the implementation of public procurement, embezzlement, clientelism (protectionism).

As for the analytical study of corruption, in general, this issue is not distinguished by a detailed study: the authors either pay attention to output statistics only, generalize the dynamics and main trends in the development of corruption, without setting as their main goal an appeal to the methodological aspects of assessing the phenomenon (Lyakhov, 2012; Krivosheeva, 2013), or disclose certain analytical methodologies, including the authors' ones (Moiseeva, 2018; Polyakov, 2017).

Probably, such fragmentation is due to the complexity of the perception of the phenomenon of corruption. Corruption as an object of empirical research can be attributed to the class of complex systems, or object-systems, constantly moving from one state to another and becoming more complicated with the increase in the number of elements, which leads to:

- the multidimensional nature of corruption as an object of research;

- difficulties in taking into account the full range of factors affecting corruption, which, moreover, differ in strength and direction;

- variability, uncertainty of direct consequences of corruption, as well as the presence of indirect impacts that are almost impossible to analyze (Polyakov, 2017: 24).

In addition, in practice, the non-aggregated data on corruption are often closed, which also makes it difficult to conduct empirical research and develop stable ways to assess the corruption status of both States as a whole and individual spheres of public life.

Taking into account the above problems, when analyzing corruption backgrounds, it is advisable to follow the methodology developed by the authors. This technique is schematically shown in Figure 1.

Based on the scheme, it is obvious that the main areas of research are the study of the scale of corruption, its causes and consequences, while the analytical "core" is the scale of corruption, since two other directions are considered on the basis of this indicator.

Each of the areas of analysis involves the use of special tools, which include various analytical methods and techniques, sampling of indicators, indexes, etc. The qualitative composition of the analytical directions of the authors' methodology for the customs sphere is given in table 1 .

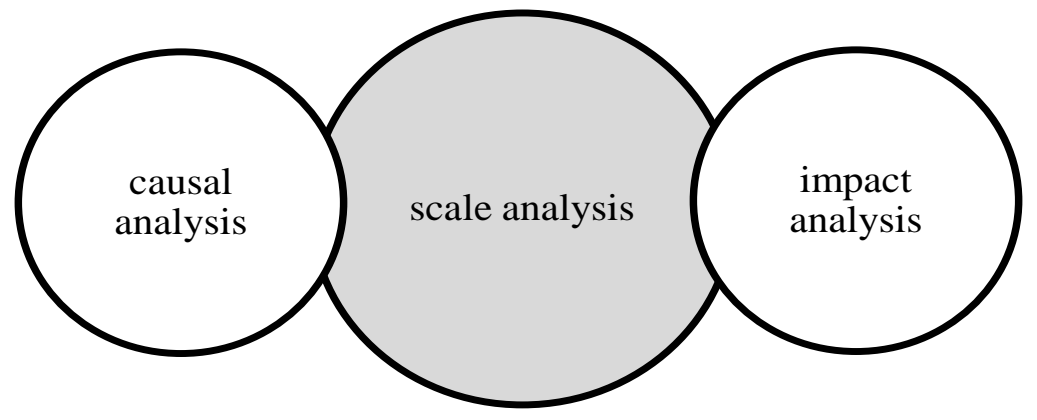

Fig. 1. The authors' methodology for the analysis of corruption backgrounds

Source: authors'own development 
Qualitative composition of the analytical directions of the authors' methodology for the customs sphere

\begin{tabular}{|c|c|c|}
\hline Analytical direction & Tools & The contents of the direction \\
\hline \multirow[b]{3}{*}{ Scale analysis } & $\begin{array}{l}\text { Analysis of the specialized } \\
\text { ratings data }\end{array}$ & $\begin{array}{l}\text { To conduct a general analysis and identify prevailing } \\
\text { trends, data from the Transparency International } \\
\text { Corruption Perceptions Index are used. }\end{array}$ \\
\hline & Mirror statistics & $\begin{array}{l}\text { Information on the import volumes of a number } \\
\text { of EAEU countries and information on the export } \\
\text { volumes of their main partners in foreign trade is } \\
\text { compared. }\end{array}$ \\
\hline & $\begin{array}{l}\text { Analysis of the number of } \\
\text { criminal cases, convicted } \\
\text { persons, etc. }\end{array}$ & $\begin{array}{l}\text { The available indicators characterizing the scale } \\
\text { of corruption crime are analyzed; the indicators } \\
\text { determining the level of corruption in customs } \\
\text { authorities are studied. } \\
\text { The General probabilistic level of corruption of } \\
\text { customs officials is calculated: } \\
\omega=N^{\prime} / N(1) \text {, } \\
\text { where } \omega \text { is the General probabilistic level of } \\
\text { corruption of customs officials, \%; } \\
\mathrm{N}^{\prime} \text { - number of convicted customs officials; } \\
\mathrm{N} \text { - number of staff of customs authorities. }\end{array}$ \\
\hline $\begin{array}{l}\text { Causal analysis and } \\
\text { impact analysis }\end{array}$ & $\begin{array}{l}\text { Construction of correlation } \\
\text { models }\end{array}$ & $\begin{array}{l}\text { The link and its intensity between corruption and } \\
\text { causal indicators / impact indicators are determined. }\end{array}$ \\
\hline
\end{tabular}

Source: authors'own development

Following the sequence of analytical directions, to review the national situation regarding the scale of corruption, it is advisable to refer to the data of the Transparency International rating data (operating principle: each state is assigned a rating from 0 (high corruption) to 100 (no corruption), according to which none of the States for 2015-2018 with the relative stability of the number of points and the gradual weakening of the positions of the leaders (Denmark - -3 points in 2018 compared to 2015, New Zealand - -4 points in 2018 compared to 2015) did not show a significant breakthrough in positions: countries have either made little progress (Kazakhstan -+1 position in 2018 to 2015)or have not reached the level of 2015, with a generally weak progressive trend (Armenia is 105th out of 180 in 2018 compared to 95th out of 167 in 2015, Kyrgyzstan is 132nd out of 180 in 2018 compared to 123rd out of 167 in 2015) or with a generally weak regressive trend (Russia ranked 138th out of 180 in 2018 compared to 119th out of 167 in 2015) (figure 2).

Also noteworthy is the appeal to the global average level of corruption, which during 2015-2018 was 43 points. In this case, it is indicative that in 2015-2018 this threshold was crossed only by Belarus in 2017-2018. Therefore, there are objective reasons to consider it the least corrupt among all member States of the EAEU.

Returning directly to the customs sphere, it should be noted that during 2015-2018 the proportion of customs officials convicted of corruption-related crimes in the total number of convicted of the same crimes is:

- for the Republic of Belarus - 2-3\%;

- for the Russian Federation - 0,3-0,6\%;

- for the Republic of Kazakhstan - 5-8\%;

- for the Republic of Armenia - 1-3\%.

- In general, this results in a relatively low overall probabilistic level of corruption of customs officials:

- for the Republic of Belarus - 0,3-0,6\%;

- for the Russian Federation - 0,1\%;

- for the Republic of Kazakhstan - 1,5-2,4\%;

- for the Republic of Armenia - 0,9-3,9\%.

At the same time, there are no data for the Kyrgyz Republic, however, the use of the mirror statistics method (comparison with the data of the people's Republic of China) allows us to establish the existence of a significant discrepancy between the value of imports and exports, which reaches the highest level 
in 2016 and amounts to about $70-75 \%$. This gives grounds to believe that there is a significant level of corruption in the customs authorities.

Qualitatively, corruption in the customs authorities of the EAEU mostly takes the form of bribery. One of its main causes, which can be quantified and therefore analyzed, is low wages (for example, for the Republic of Belarus, the correlation coefficient between the level of wages and the level of corruption for the study period is $-0,84$ (strong correlation). This suggests an inverse relationship between these indicators). The main consequence of corruption in the customs authorities of the EAEU, available for analytical research, is the shortfall of funds in the budget (for example, the Kyrgyz Republic, the correlation coefficient between the level of corruption and the amount received in the budget of customs payments for the study period is $-0,98$ (very strong correlation) which indicates an inverse relationship between these two indicators), secondary are inflation, lower inflows of foreign direct investment.

\section{Findings}

Thus, it is obvious that corruption in the customs authorities is a threat to the national security of the EAEU member States and should be reduced to an achievable minimum.

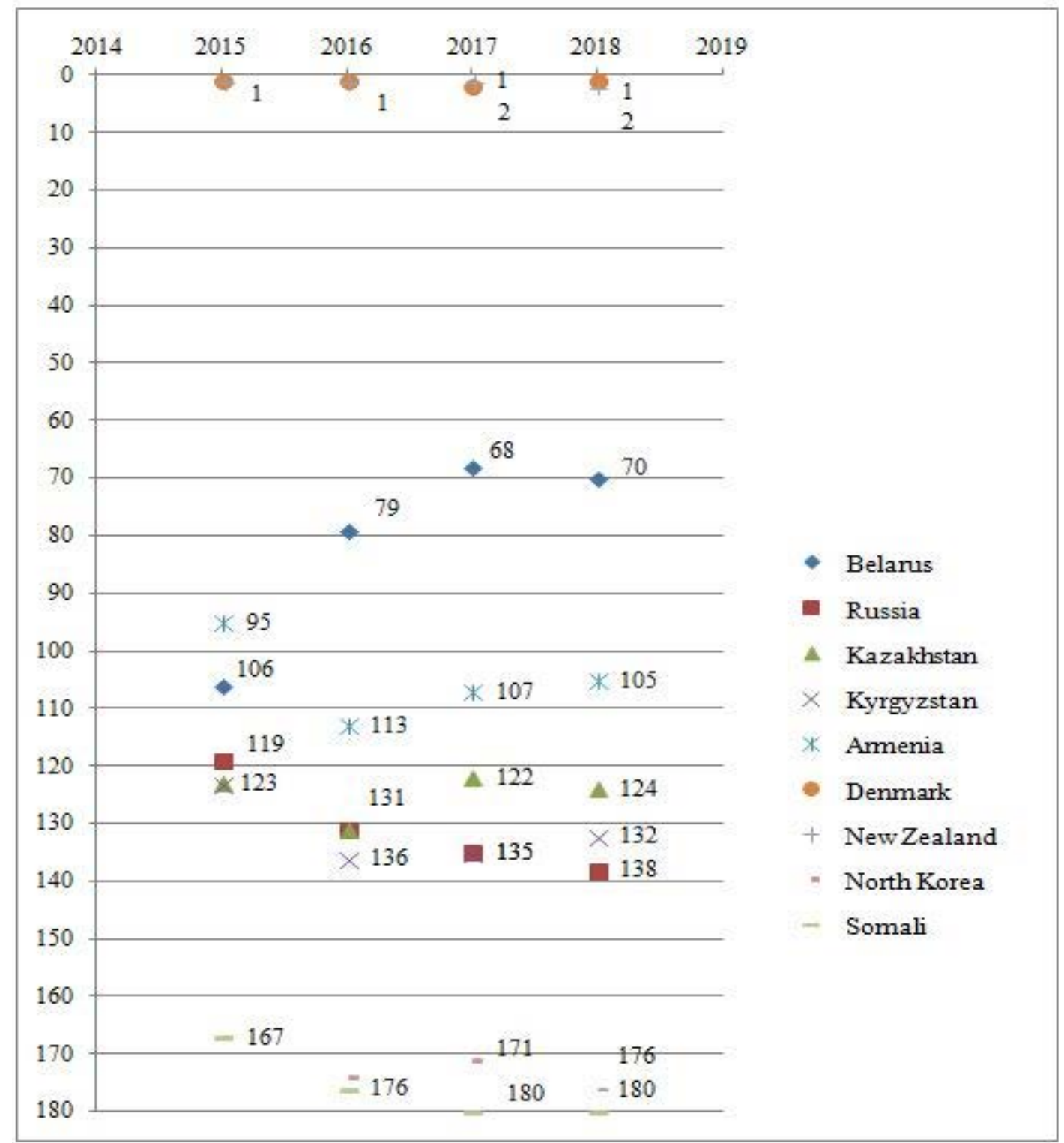

Fig. 2. Ranking of the EAEU member States in the Index in comparison with the best and worst indicators in 2015-2018

Source: authors'own development based on (Transparency International, 2014; Transparency International, 2015; Transparency International, 2016; Transparency International, 2018) 
The least corrupt state in the EAEU is Belarus, where the level of corruption by 2018 fell below the global average, which was not observed in any of the EAEU member States during 2015-2018; the most corrupt are Russia and Kazakhstan; the relatively high level of corruption in the region as a whole is due to the fragility of the main democratic institutions, which are still in the process of formation and are not fully functioning.

Among the customs authorities, the most corrupt is the State Customs Service under the Government of the Kyrgyz Republic; the lowest corruption indicators are for the customs authorities of Belarus and Russia. One of the main causes of corruption in customs is the low level of salaries of officials; there is a strong inverse correlation between the scale of corruption and average wages in the agency.

The most significant consequence of corruption in the customs authorities for the EAEU is the shortfall of customs payments in the budget, which increases with the enlargement of its scale.

The main direction of stabilization of the corruption background is seen as increasing the effectiveness of the corruption risk management system through:

- integrated automation (in accordance with the requirements of the Arusha Declaration) and the use of information technologies (such as blockchain - technologies on the example of the South Korean Logistics service for export clearance (Kang, 2019), which allows to increase the transparency of transactions and prevents fraud, strengthening accountability and expanding the control capabilities that is because all the information is stored in blocks, which cannot be modified or removed);

- enhancing cooperation between customs authorities and other state agencies and the business community (for example, by drafting anti-corruption pacts and declarations, signing memorandums of understanding, etc.);

- improvement of anti-corruption legal regulation(for example, the introduction of confiscation "in rem", the meaning of which is that at the request of the Prosecutor, the court decides to confiscate to the state money and other property that are not the subject of the crime, but found in the suspect or accused, if there is sufficient evidence to believe that these funds and property are obtained by these persons without legal grounds; the obligation to prove the legality of the origin of the property falls on the owner of this property).

\section{References:}

1. Nomokonov, V.A. (2001). On the anti-corruption strategy in Russia. Corruption: political, economic, organizational and legal problems: proceedings of the International scientific and practical conference (Moscow, September 8-10, 1999) / ed. by V.V. Luneev. Moscow: Institute of state and law RAS, pp. 166 [in Russian].

2. McLinden, G., Durrani, A.Z. (2013). Corruption in Customs. World Customs Journal, vol. 7, no. 2, pp. 3-9 [in English].

3. Miller \& Chevalier (2018). A study of corruption in the region of Europe, the Caucasus and Asia. Retrieved from: https://www.millerchevalier.com/sites/default/files/resources/2018-ECA-Corruption-SurveyFull-Report-Russian.pdf (date of access: 20.08.2019) [in Russian].

4. Simanovskiy, S.I. (2017). Social and legal aspects of corruption. Constitutional and legal foundations of combating corruption as the most important condition for ensuring sustainable socio-economic balance: collection of materials of the round table (Minsk, March 4, 2017) / ed. by G.A. Vasilevich et al. Minsk: Belarusian State University, pp. 123-130 [in Russian].

5. Widdowson, D. (2013). Bordering on corruption: an analysis of corrupt customs practices that impact the trading community. World Customs Journal, vol. 7, no. 2, pp. 11-21 [in English].

6. Lyakhov, V. (2012). International cooperation in the fight against corruption in the customs authorities. Actual issues of customs: the scientific work of the department of customs. Minsk: Belarusian State University, vol. 2, pp. 201-223 [in Russian].

7. Krivosheeva, A. (2013). Fighting corruption in the customs authorities of the Republic of Belarus. Customs and foreign economic activity: a collection of reports of participants of the SRL "Theory and Practice of Customs and Foreign Economic Activity" / ed. by V.V. Lyakhovsky. Minsk: Belarusian State University, vol. 1, pp. 19-28 [in Russian].

8. Moiseeva, I.A. (2018). Corruption perception index as an indicator of the degree of corruption in a single country and the world. Actual problems of economics and law, vol. 12, no. 1, pp. 89-100 [in Russian].

9. Polyakov, S.V. (2017). Forecasting changes in the index of the Corruption Perception Index in Russia. Academic notes, no. 1, pp. 24-28 [in Russian].

10. Transparency International (2018). Corruption Perceptions Index 2018. Retrieved from: https://www.transparency.org/cpi2018 (date of access: 09.04.2019) [in English].

11. Transparency International (2014). Corruption Perceptions Index 2014: results. Retrieved from: https://www.transparency.org/cpi2014/results (date of access: 09.04.2019) [in English]. 
12. Transparency International (2015). Corruption Perceptions Index 2015. Retrieved from: https://www.transparency.org/cpi2015 (date of access: 09.04.2019) [in English].

13. Transparency International (2016). Corruption Perceptions Index 2016. Retrieved from: https://www.transparency.org/news/feature/corruption_perceptions_index_2016 (date of access: 09.04.2019) [in English].

14. Kang, T. (2019). Korea pilots blockchain technology as it prepares for the future. WCO News, no. 88, pp. 32-35 [in English].

\title{
УПРАВЛІННЯ КОРУПЦІЙНИМИ РИЗИКАМИ \\ В МИТНИХ ОРГАНАХ ЄВРАЗІЙСЬКОГО ЕКОНОМІЧНОГО СОЮЗУ В КОНТЕКСТІ НАЦІОНАЛЬНОЇ БЕЗПЕКИ
}

\author{
Геннадій БРОВКА, \\ декан факультету технологій управління та гуманітаризаиії \\ Білоруського національного технічного університету, \\ кандидат педагогічних наук, дочент \\ gbrovka@bntu.by \\ https://orcid.org/0000-0001-6135-6738
}

Стаття розглядає явище корупиії, ї̈ сутність, причини та наслідки. Соціальні, економічні й політичні зміни, спричинені глобалізацією, супроводжуються певними проблемами. Одна з них - корупиія. Корупиія спостерігається на всіх рівнях суспільства в усьому світі: у місиевих і державних органах влади, органах громадянського суспільства, судових органах, великому та малому бізнесі, військових та інших служббах, у тому числі в митній. Корупиія становить серйозну загрозу для національної, економічної та інноваційної безпеки будь-якої держави. Основна загроза стосується економічної безпеки держави, щяо впливає на розиирення тіньової економіки, зростання інфляиії, підвищення рівня комериійних і фінансових ризиків, а також стимулювання неефективного використання бюджетних коштів. Проблема корупиї̈ в Свразійському економічному союзі, зокрема в його митних органах, $\epsilon$ надзвичайно актуальною. Можна констатувати необхідність вивчення чинних методів управління корупщійними ризиками в митних органах Євразійського економічного союзу, їхніх переваг і недоліків, а також потенційних сфер удосконалення. Всесвітня митна організаиія звернула увагу на міжнародний характер иього явщща та розробила єдиний підхід і методологію вивчення корупційних процесів у митній сфері. Пильна увага приділяється корупщії в митних органах, яка має специфічні особливості. Здійснено порівняльний економічний аналіз корупиї̈ в митних органах Євразійського економічного союзу та визначено, щзо ї̈ обсяг прямо пропориійний обсягу інфляиії й обернено пропориійний обсягам заробітної плати митних службовиів, митних платежів і прямих іноземних інвестицій. 3 огляду на зазначене можна виділитизаходи, спрямовані назапобігання корупщіїтаїіпридушення. Загаломєрізноманітні інноваційні заходи, які ефективно застосовуються зарубіжними країнами. Розглядаються антикорупційні засоби, що використовуються у практиці зарубіжних країн. Визначено шляхи вдосконалення протидї корупції, з'ясовано антикорупційні інструменти в митних органах Євразійського економічного союзу.

Ключові слова: державна політика, корупція, корупційні ризики, національна безпека, економічна безпека, митні органи, антикорупційні інструменти. 